\title{
Simultaneous HPTLC Determination of Nabumetone and Paracetamol in Combined Tablet Dosage Form
}

\author{
Santosh V. Gandhi,* Sandeep S. Ranher, Padmanabh B. Deshpande and Dixit K. Shah \\ Department of Pharmaceutical Analysis, AISSMS College of Pharmacy, Kennedy Road, \\ Pune - 411 00, Maharashtra, India
}

\begin{abstract}
Um novo método de cromatografia em camada delgada de alta eficiência (HPTLC) para determinação simultânea de nebumetona e paracetamol em forma combinada em comprimido foi desenvolvido e validado. As separações foram efetuadas em placas de alumínio prerrecobertas com sílica gel $60 \mathrm{~F}_{254}$ utilizando tolueno:propanol-2:ácido acético (8:2:0.1, v/v/v) como fase móvel. A determinação quantitativa das bandas foi feita por varredura densitométrica a $236 \mathrm{~nm}$. Os fatores de retenção calculados para nebumetona e paracetamol foram $0,78 \pm 0,03$ e $0,32 \pm 0,03$, respectivamente. O método foi validado com relação à linearidade, exatidão, precisão e robustez. A curva de calibração mostrou-se linear dentro do intervalo de 50-250 ng por banda de ambas as drogas. O método tem sido aplicado com sucesso nas análises das drogas em formulações farmacêuticas. As porcentagens de precisão de ensaio (média \pm desvio padrão) foram 99,89 $\pm 1,15$ para nabumetona e 101,10 \pm 0,71 para paracetamol, ambos de comprimidos disponíveis comercialmente.
\end{abstract}

A new simple high performance thin layer chromatographic method (HPTLC) for simultaneous determination of nabumetone and paracetamol in combined tablet dosage form was developed and validated. The separations were carried out on Merck aluminum plates precoated with silica gel $60 \mathrm{~F}_{254}$, using toluene:2-propanol:acetic acid (8:2:0.1, v/v/v) as mobile phase. Quantitative determination of bands was done by densitometric scanning at $236 \mathrm{~nm}$. The calculated retention factors for nabumetone and paracetamol were $0.78 \pm 0.03$ and $0.32 \pm 0.03$, respectively. The method was validated with respect to linearity, accuracy, precision and robustness. The calibration curves showed to be linear over a range of 50-250 ng per band for both drugs. The method has been successfully applied for the analysis of drugs in pharmaceutical formulation. The percentages of assay (mean \pm S.D.) were $99.89 \pm 1.15$ for nabumetone and $101.10 \pm 0.71$ for paracetamol, both of commercially available tablets.

Keywords: nabumetone, paracetamol, high performance thin layer chromatography (HPTLC), tablet dosage form

\section{Introduction}

Nabumetone (NAB), chemically, 4-(6-methoxy-2naphthyl)-2-butanone is a non-steroidal anti-inflammatory drug of the arylalkanoic acid family used to treat pain or inflammation caused by arthritis, ${ }^{1}$ being official in British Pharmacopoeia $^{2}$ and United States Pharmacopeia ${ }^{3}$ and Indian Pharmacopeia. ${ }^{4}$ Paracetamol (PAR), 4-hydroxyacetanilide is a widely-used analgesic and antipyretic drug. ${ }^{5}$

The literature survey reveals that several chromatographic methods have been used for the analysis of NAB in biological fluids ${ }^{6-11}$ and in pharmaceutical formulations. ${ }^{10-12}$ Also colorimetric ${ }^{13}$ and micellar stabilized

*e-mail: santoshvgandhi@rediffmail.com room temperature phosphorescence quantitation ${ }^{14}$ of NAB as single component, or in combinations with other drugs, has been reported. Analytical methods have been reported for the determination of PAR including: high-performance liquid chromatography-diode array (HPLC-DAD) with online post-column photochemical derivatization, ${ }^{15}$ non-suppressed ion chromatography(IC), ${ }^{16} \mathrm{UV}$-Visible spectrophotometry, ${ }^{17}$ HPLC, ${ }^{17-20}$ gas chromatographmass spectrometry (GC-MS) ${ }^{21}$ as single component or in combinations with other drugs. The chemical structures of the drugs are given in Figure 1.

No reports were found for simultaneous determination of NAB and PAR in combined tablet dosage form by high performance thin layer chromatographic method (HPTLC). This paper describes simple, accurate, precise and sensitive 


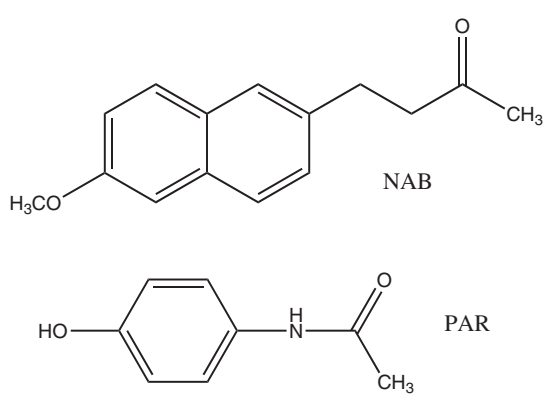

Figure 1. Chemical structures of NAB and PAR.

HPTLC method for simultaneous determination of NAB and PAR in combined tablet dosage form. The proposed HPTLC method can be used for analysis of ten or more formulations on a single plate and is a rapid and costeffective quality-control tool for routine simultaneous analysis of drugs. The technique is simpler and provides more flexibility than HPLC. The method was optimized and validated as per the International Conference on Harmonization (ICH) guidelines. ${ }^{22}$

\section{Experimental}

\section{Reagents and chemicals}

Authentic samples of NAB and PAR were obtained from Divi's Laboratories Ltd. (Hyderabad, India) and Cipla Ltd. (Pune, India), respectively, used as such without further purification. Brand of tablets Niltis P (Ipca laboratories Ltd., India), labeled to contain $500 \mathrm{mg}$ of NAB and $500 \mathrm{mg}$ of PAR were procured from the local market. Methanol, toluene, 2-propanol and acetic acid (all AR grade) were obtained from Sisco Research Laboratories (Mumbai, India). Silica gel $60 \mathrm{~F}_{254}$ TLC plates $(20 \times 20 \mathrm{~cm}$, layer thickness $0.2 \mathrm{~mm}$, from Merck, Germany) were used as stationary phase.

\section{Preparation of standard stock solutions}

Standard stock solution of NAB and PAR was prepared by dissolving $10 \mathrm{mg}$ of each drug in $10 \mathrm{~mL}$ of methanol separately to get concentration of $1 \mathrm{mg} \mathrm{mL}^{-1}$ from which 0.5 was further diluted to $10 \mathrm{~mL}$ to get stock solution of $50 \mathrm{ng}^{-1} \mathrm{l}^{-1}$ of each drug.

\section{Chromatographic condition}

The plates were prewashed with methanol and activated at $110{ }^{\circ} \mathrm{C}$ for $5 \mathrm{~min}$, prior to chromatography. The slit with dimensions of $5 \times 0.45 \mathrm{~mm}$ and scanning speed of $20 \mathrm{~mm} \mathrm{~s}^{-1}$ were employed. The linear ascending development was carried out in $10 \times 10 \mathrm{~cm}$ twin trough glass chamber (Camag, Muttenz, Switzerland) using toluene:2-propanol:acetic acid (8:2:0.1, v/v/v) as mobile phase, after saturation of the chamber with mobile phase vapor for $10 \mathrm{~min}$. The development distance and time were $9 \mathrm{~cm}$ and $20 \mathrm{~min}$, respectively. After, chromatography plates were dried in a current of air with the help of a hair dryer. A Camag HPTLC system containing Camag Linomat V semiautomatic sample applicator, Hamilton syringe $(100 \mu \mathrm{l})$, Camag TLC Scanner-3 with winCATS software version 1.4.2 and Camag twin- trough chamber $(10 \times 10 \mathrm{~cm})$ were used for the present study. The source of radiation utilized was deuterium lamp emitting a continuous UV spectrum between 200 to $400 \mathrm{~nm}$.

\section{Selection of detection wavelength}

After chromatographic development bands were scanned over the range of $200-400 \mathrm{~nm}$ (with a spectrum scan speed of $100 \mathrm{~nm} \mathrm{~s}^{-1}$ ) and the spectra were overlain. It was observed that both drugs showed considerable absorbance at $236 \mathrm{~nm}$, which was selected as the wavelength for detection (Figure 2).

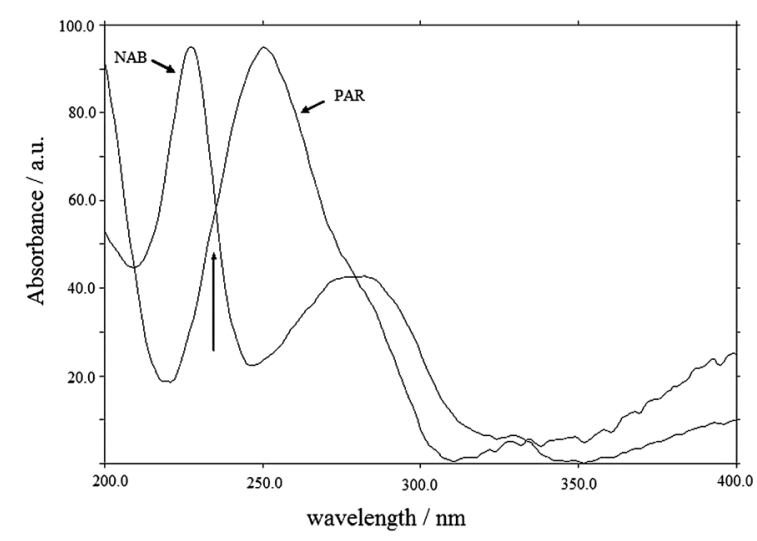

Figure 2. Overlain UV spectra of nabumetone and paracetamol.

\section{Preparation of calibration curves}

The standard stock solutions of NAB and PAR (50 ng $\mu \mathrm{L}^{-1}$ each) were applied by overspotting on TLC plate in range of 1-5 $\mu \mathrm{L}$ with the help of CAMAG $100 \mu \mathrm{L}$ sample syringe, using Linomat 5 sample applicator to get concentrations 50,100, 150, 200 and $250 \mathrm{ng}$ per band. The plate was developed and scanned under above established chromatographic conditions. Each standard in five replicates was analyzed and peak areas were recorded. Calibration curves of NAB and PAR were plotted separately of peak area $v s$. respective concentration of NAB and PAR. 


\section{Analysis of tablet formulation}

Twenty tablets were weighed accurately and finely powdered. A quantity of powder equivalent to $10 \mathrm{mg}$ of each NAB and PAR was weighed and transferred to a $10 \mathrm{~mL}$ volumetric flask containing approximately $7 \mathrm{~mL}$ of methanol, ultrasonicated for $5 \mathrm{~min}$, and volume was made up to the mark with the methanol. The solution was filtered through Whatman 41 filter paper, and $0.5 \mathrm{~mL}$ of filtrate was further diluted to $10 \mathrm{~mL}$ with methanol. Then, $2 \mu \mathrm{L}$ volume were were applied to a TLC plate to furnish final concentration of $100 \mathrm{ng}$ per band for both NAB and PAR. After chromatographic development the peak areas of the bands were measured at $236 \mathrm{~nm}$ and the amount of each drug present in sample was estimated from the respective calibration curves. Procedure was repeated six times for the analysis of homogenous sample.

\section{Recovery studies}

To check the accuracy of the method, recovery studies were carried out by addition of standard drug solution to preanalyzed sample solution at three different levels, 50, 100 and $150 \%$. Chromatogram was developed and the peak areas were noted. At each level of the amount, three determinations were carried out.

\section{Precision}

Set of three different concentrations in three replicates of mixed standard solutions of NAB and PAR were prepared. All the solutions were analyzed on the same day in order to record any intra-day variations in the results. For inter-day variation study of three different concentrations of the mixed standard solutions in linearity range were analyzed on three consecutive days.

\section{Robustness studies}

In the robustness study, the influence of small, deliberate variations of the analytical parameters on peak area of the drugs were examined. Factors varied were development distance $( \pm 5 \%)$, time from application to development $(0,10,20$ and $30 \mathrm{~min})$ and from development to scanning $(0,30,60$, and $90 \mathrm{~min})$. One factor at a time was changed to study the effect. Robustness of the method was checked at a concentration level of $100 \mathrm{ng}$ per band for both NAB and PAR.

\section{Results and Discussion}

Different mobile phases containing various ratios of toluene, methanol, acetic acid were examined (data not shown). Finally the mobile phase containing toluene:2-propanol:acetic acid (8:2:0.1, v/v/v) was selected as optimal for obtaining well defined and resolved peaks. The optimum wavelength for detection and quantitation used was $236 \mathrm{~nm}$. The retention factors for NAB and PAR were found to be $0.78 \pm 0.03$ and $0.32 \pm 0.03$, respectively. Representative densitogram obtained from a mixed standard solution of NAB and PAR is shown in Figure 3.

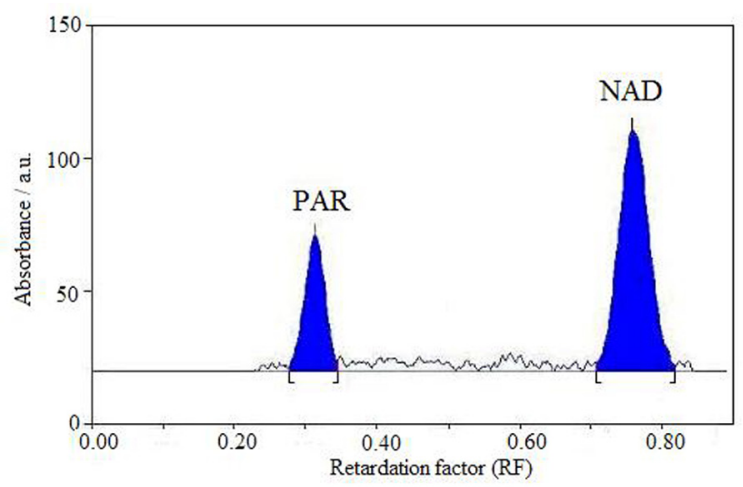

Figure 3. Representative chromatogram of mixed standard solution of NAB (100 ng per band, $R_{\mathrm{f}}=0.78 \pm 0.03$ ) and PAR (100 ng per band, $\left.\mathrm{R}_{\mathrm{f}}=0.32 \pm 0.03\right)$.

Straight-line calibration graphs were obtained for NAB and PAR in the concentration range 50-250 ng per band for both the drugs with high correlation coefficient $>0.999$ (Figure 4). For NAB, the percentage of recovery study ranged from 99.44 to $100.41 \%$ with $\%$ RSD values ranging from 0.85 to $1.28 \%$. For PAR, the recovery results ranged from 99.41 to $100.77 \%$ with $\%$ RSD values ranging from 0.99 to $1.34 \%$. The method was found to be accurate and precise, as indicated by recovery studies as recoveries were close to $100 \%$ and \% RSD not more than 2 . Results of recovery studies are reported in Table 1. Intra-day variation, as \% RSD, was 0.78 for NAB and 0.92 for PAR. Inter-day variation, as \% RSD was 1.64 for NAB and 1.43 for PAR, as presented in Table 2.

Robustness of the method checked after deliberate alterations of the analytical parameters showed that areas of peaks of interest remained unaffected by small changes of the operational parameters $(\% \mathrm{RSD}<2)$. The results are given in Table 3 . The proposed method was also evaluated by the assay of commercially available tablets containing $\mathrm{NAB}$ and PAR. The $\%$ of assay (mean \pm S.D.) was found to be $99.89 \pm 1.15$ for NAB and $101.10 \pm 0.71$ for PAR.

\section{Conclusions}

The validated HPTLC method employed proved to be simple, fast, accurate, precise and robust, thus can be used for routine analysis of NAB and PAR in combined tablet dosage form. 
Table 1. Recovery studies of NAB and PAR

\begin{tabular}{|c|c|c|c|c|c|c|}
\hline Drug & $\begin{array}{l}\text { Level of \% of } \\
\text { recovery }\end{array}$ & $\begin{array}{l}\text { Amount taken } \\
\text { (ng per band) }\end{array}$ & $\begin{array}{c}\text { Amount added } \\
\text { (ng per band) }\end{array}$ & $\begin{array}{l}\text { Total amount found } \\
\text { (ng per band) }\end{array}$ & $\%$ of recovery ${ }^{a}$ & $\% \mathrm{RSD}^{\mathrm{a}}$ \\
\hline \multirow[t]{3}{*}{$\mathrm{NAB}$} & 50 & 100 & 50 & 149.35 & 99.57 & 1.19 \\
\hline & 100 & 100 & 100 & 200.82 & 100.41 & 1.28 \\
\hline & 150 & 100 & 150 & 248.60 & 99.44 & 0.85 \\
\hline \multirow[t]{3}{*}{ PAR } & 50 & 100 & 50 & 149.58 & 99.72 & 1.34 \\
\hline & 100 & 100 & 100 & 198.82 & 99.41 & 1.14 \\
\hline & 150 & 100 & 150 & 251.92 & 100.77 & 0.99 \\
\hline
\end{tabular}

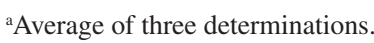
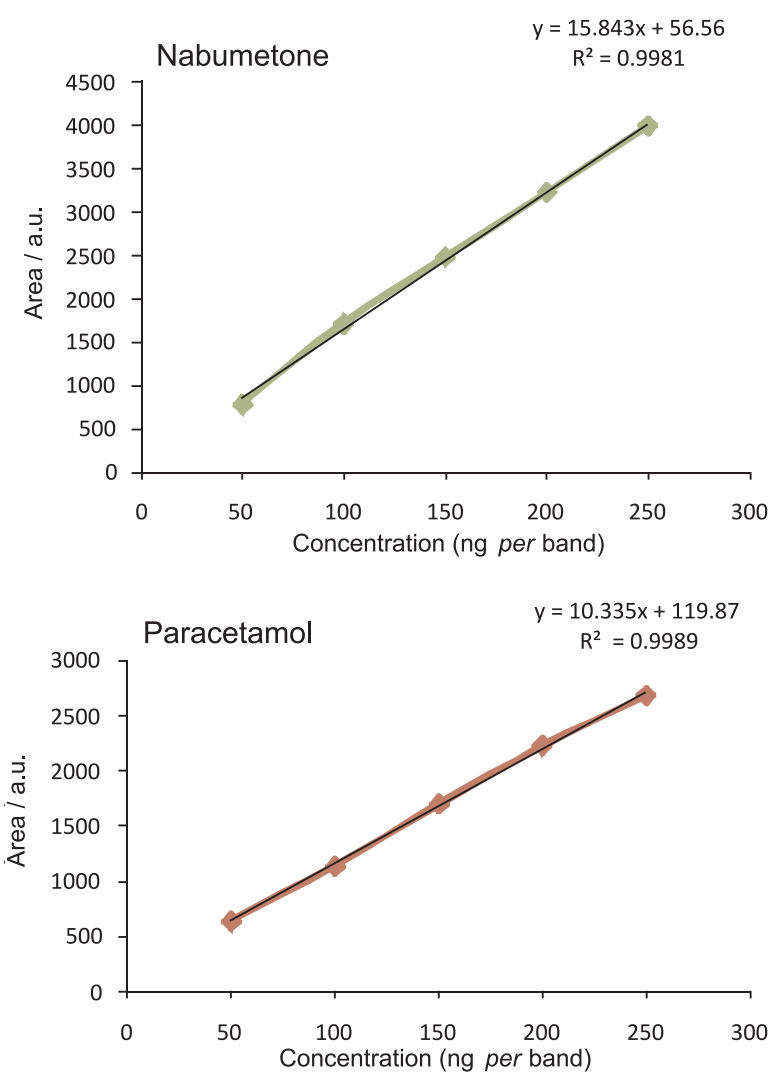

Figure 4. Calibration curves for NAB and PAR.

\section{Acknowledgement}

The authors wish to express their gratitude to M/s Divi's Laboratories Ltd. (Hyderabad, India) for the sample of pure nabumetone and M/s Cipla Ltd. (Kurkumbh, India) for the sample of pure paracetamol.

\section{References}

1. http://en.wikipedia.org/wiki/nabumetone accessed in April 2008.

2. The United States Pharmacopeial Convention, The United States Pharmacopeia, $29^{\text {th }}$ ed., Rockville, 2006.
Table 2. Percentages of recovery for intra- and inter-day variation studies

\begin{tabular}{lcccc}
\hline $\begin{array}{l}\text { Concentration } \\
\text { (ng per band) }\end{array}$ & \multicolumn{2}{c}{ NAB (\% of recovery) } & \multicolumn{2}{c}{ PAR (\% of recovery) } \\
\hline 100 & 100.53 & 100.09 & 100.6 & 99.23 \\
100 & 98.65 & 99.79 & 99.53 & 100.78 \\
100 & 99.53 & 101.36 & 98.48 & 98.12 \\
150 & 101.1 & 102.89 & 99.78 & 98.52 \\
150 & 99.86 & 99.85 & 98.54 & 100.65 \\
150 & 99.12 & 98.12 & 98.69 & 99.38 \\
200 & 99.87 & 101.89 & 100.6 & 98.58 \\
200 & 100.07 & 98.42 & 98.32 & 102.7 \\
200 & 98.89 & 98.56 & 98.62 & 99.73 \\
Mean & 99.74 & 100.11 & 99.24 & 99.74 \\
\% of recovery) & & & & \\
$\%$ RSD & 0.78 & 1.64 & 0.92 & 1.43 \\
\hline
\end{tabular}

Table 3. Relative standard deviation of peak area obtained under robustness study

\begin{tabular}{lccc}
\hline $\begin{array}{l}\text { Serial } \\
\text { Number }\end{array}$ & Parameter varied & NAB & PAR \\
\hline 1 & development distance & 0.96 & 0.68 \\
2 & time from application to development (min) & 0.84 & 0.49 \\
3 & time from development to scanning (min) & 1.12 & 0.62 \\
\hline
\end{tabular}

3. The Official Compendia of Standards, British Pharmacopoeia, vol. 1, Her Majesty's Stationery Office: London, 1993.

4. The Official Compendia of Standards, Indian Pharmacopoeia, vol. 2, the Controller of Publication: New Delhi, 1996.

5. http://en.wikipedia.org/wiki/paracetamol accessed in April 2008.

6. AL-Momani, I. F.; Anal. Lett. 1997, 30, 2485.

7. Kobylinska, K.; Barlinska, M.; Kobylinska, M.; J. Pharm. Biomed. Anal. 2003, 32, 323.

8. Nobilis, M.; Kopecky, J.; Kvetina, J.; Svoboda, Z.; Pour, M.; Kunes J.; Holcapek, M.; J. Pharm. Biomed. Anal. 2003, 32, 641.

9. Nobilis, M.; Holcapek, M.; Kolárová, L.; Kopecký, J.; Kunes, M.; Svoboda, Z.; Kvetina, J.; J. Chromatogr. A 2004, 1031, 229. 
10. Mikami, E.; Goto, T.; Ohno T.; Matsumoto, H.; Nishida, M.; J. Pharm. Biomed. Anal. 2000, 23, 917.

11. Rao,R. N.; Meena, S.; Nagaraju, D.; Rao, A. R. R.; Biomed. Chromatogr. 2004, 19, 362.

12. Can, N. O.; Tuncel, M.; Aboul-Enein, H. Y.; Pharmazie 2003, $58,22$.

13. Rao, Y. S.; Chowdary, K. P. R.; Rao, J. V.; Seshagiri, L. N.; Indian J. Pharm. Sci. 2003, 65, 206.

14. Murilo, P. J. A.; Alañón, M. A.; Alañón, P. M. T.; Anal. Chim. Acta 2005, 528, 77

15. Di Pietra, A. M.; Gatti, R.; Andrisano, V.; Cavrini, V.; J. Chromatogr. A 1996, 729, 355.

16. Perez, J. L.; Bello, M. A.; Talanta. 1999, 48, 1199.

17. Dinc, E.; Kokdil, G.; Onur, F.; J. Pharm. Biomed. Anal. 2001, 26, 769.
18. Franeta, J. T.; Agbaba, D.; Eric, S.; Pavkov, S.; Aleksic, M. Vladimirov, S.; Il Farmaco 2002, 57, 709.

19. Momin, M. Y.; Yeole, P. G.; Puranik, M. P.; Wadher, S. J.; Indian J. Pharm. Sci. 2006, 68, 387.

20. Panusa, A.; Multari, G.; Incarnato, G.; Gagliardi, L.; J. Pharm. Biomed. Anal. 2007, 43, 1221.

21. Alves, T. M. A.; Augusti, R.; J. Braz. Chem. Soc. 2008, $19,81$.

22. ICH, International Conference on Harmonization of Technical Requirements for Registration of Pharmaceuticals for Human Use, Q2B(R1), Guideline on Validation of Analytical Procedure: Text and Methodology, Geneve, 2005.

Submitted: May 5, 2010

Published online: February 15, 2011 